\title{
Performance E EDUCAÇÃO: UMA REFLEXÃO DE PROFESSORES KRAHÔ SOBRE A INCORPORAÇÃO DE RITOS E CANTOS NA PRÁTICA DA EDUCAÇÃO ESCOLAR INDÍGENA
}

\author{
Mônica Thereza Soares Pechincha \\ Universidade Federal de Goiás (UFG), Goiânia, Goiás, Brasil
}

\begin{abstract}
Resumo: Com o intuito de contribuir com a discussão da educação escolar indígena, este artigo pontua a reflexão de professores krahô ${ }^{1}$ sobre a incorporação de rituais e cantos - ações axiais em sua cultura - nas suas escolas e na construção própria de seus projetos pedagógicos. Apresenta, sucintamente, aspectos estilísticos e cosmológicos de sua performance e sua conexão com o que chamamos de "natureza" e "sobrenatureza". A análise resulta de observações e reflexões conjuntas com professores krahô no contexto de sua formação no curso de Educação Intercultural na Universidade Federal de Goiás.
\end{abstract}

Palavras-chave: Ritual. Cantos. Krahô. Educação escolar indígena.

A motivação para investigar os repertórios de cantos krahô adveio de meu trabalho com professores krahô no contexto Curso de Educação Intercultural para formação de professores indígenas na Universidade Federal de Goiás, que conta atualmente com alunos/as krahô, apinajé, gavião pucobjê, krinkati, canela, karajá, javaé, xambioá, tapuio, tapirapé, guajajara, kamayurá, wará, kuikuro, xerente, xavante e xacriabá. No referido curso, os/as professores/as indígenas encontram amplo estímulo e apoio para expressarem-se em termos de seus conhecimentos tradicionais e debruçarem-se em ações de pesquisa sobre esses conhecimentos. Esta prática corresponde a princípios do curso de Educação Intercultural, que advoga pela equivalência de valor entre diferentes 
formas de conhecimento e permite paralelizar os chamados conhecimentos ocidentais, sobretudo os científicos e tidos como "universais" para, assim, facultar a problematização, entre os envolvidos no curso, sobre marcos epistemológicos distintos, que são também culturais, sejam os nossos ou os indígenas.

Os Krahô são falantes de língua da família jê, do grupo timbira (RODRIGUES, 1986, p. 47), assim como os Canela, os Krinkati, os Gavião Pukobjê, entre outros povos. Quando nos referimos ao conjunto desses povos, seguimos o critério linguístico e usamos a denominação Timbira, que os envolve a todos e que também remete a uma grande proximidade entre eles de organização social e cosmológica. Quando os Krahô, como também os outros timbira que participam do curso, objetivam o que seriam os seus conhecimentos, dispõem, invariavelmente, no rol de temas que assim qualificam, algumas características que Nimuendajú (1946) há muito já havia arrolado como inseparáveis da autodefinição timbira de sua identidade. Entre essas características encontram-se a corrida de toras, a língua, o corte de cabelo, a etiqueta de parentesco e, sobretudo, as "festas", como os Krahô designam em português a palavra amjĩ kĩn, (amjĩ = junto, kĩn = alegre - conforme grafia indicada pelos professores $\mathrm{Krahô}^{2}$ e a tradução que fizeram dessa palavra com sentido referido especificamente ao tema que estávamos discutindo). Encontra-se também a prática de nominação, que consiste em sistema de transmissão de nomes pessoais, em que os indivíduos do sexo masculino e do sexo feminino recebem o nome de determinadas categorias de parentes, sobretudo do irmão da mãe e da irmã do pai, respectivamente. Aquele ou aquela que é nominado recebe, com o nome, uma série de relações sociais com pessoas ligadas ao seu nominador também pelo nome, bem como papeis rituais. Os repertórios de nomes krahô estão associados a dois pares de metades, Katamjê e Wakmẽjê, as quais cada krahô pertence pelo nome pessoal (MELATTI, 1976).

Para realçar a importância das festas amjĩ kĩn entre os Krahô, remeto ao extenso livro do antropólogo J. C. Melatti (1978), no qual estão descritos, em grande detalhe, cerca de quarenta ritos. $O$ autor explica que os rituais que descreveu estão associados a repertórios específicos de cantos e dividem-se, entre outros critérios, entre ritos que podem ser encenados em qualquer dia, ou aqueles que se desenvolvem em períodos mais longos e determinados do ano. Ao explicar o tipo de ritos que descreveu, Melatti afirma que todos poderiam ser incluídos dentro da categoria krahô amnihkhĩ, ou, como traduz o autor, "alegria", palavra "que pode ser usada em frases tais como i mã amnikhĩ, 'eu estou alegre"' (1978, p. 14). De fato, os/as estudantes krahô afirmam que os 
amjĩ kĩn "são para a alegria do povo" e que não são rituais do tipo a que os não índios poderiam associar a práticas religiosas: estes últimos, dizem os Krahô"são assunto de'pajelança', são outra coisa". Wajaca, é a palavra na língua krahô para "pajé", mas os Krahô usam sempre a forma tupi quando falam em português.

Ainda insistindo na importância que conferem os Krahô, como os Timbira em geral, a tais "festas" e seu sentido de "estarem alegres juntos", refiro-me à tese de Siqueira Jr., que versa sobre o movimento político timbira, onde conclui que, para esses povos, a "plena efetivação dos amji'kin aparece com um dos principais meios para se alcançar os desejáveis e idealizados padrões de bem-estar e felicidade..." (2007, p. 6, grifo meu).

Encontrei entre os Krahô a mesma afirmação de que amjĩ kĩn corresponde, mais do que qualquer outra prática cultural, ao "jeito de viver" específico e característico dos Krahô. Ademais, como explicam os professores krahô, na "festa" convergem muitos de seus distintivos culturais, como as pinturas corporais (que são indispensáveis nos momentos rituais), a corrida de toras (há entre eles uma classificação de corridas de toras distintas, associadas a rituais definidos), o corte de cabelos, o preparo de comidas, as obrigações de parentesco entre outras. Não é sem interesse que a palavra amjĩ componha a expressão que os professores krahô usam para designar "cultura", quando indagamos se haveria uma expressão ou palavra na língua deles que pudesse servir de tradução para o que entendem quando os não índios dizem "cultura". Tal expressão seria mẽ pahte amjĩ ton xà (que se refere ao ato de fazer alguma coisa juntos) - com a ressalva feita por eles mesmos de que a expressão amjĩ kĩn também poderia ser usada com o mesmo fim de traduzir a palavra "cultura" ou "jeito de viver" (Mehĩ te amjĩ kĩn amjĩ ton xà, que traduziram como "jeito de viver dos Krahô"). Assim, acompanho o que afirmam os professores krahô em formação na UFG ao entender amjĩ kĩn como prática axial em sua cultura, o que poderia ser apontado como uma redundância, já que os termos se traduzem. Destaco, já chamando a atenção para a reflexão que fazem sobre o que seria uma prática pedagógica própria e como a mesma poderia refletir em sua escola, a centralidade da experiência prática e corporal de sua "cultura". Ademais, o verbo que acompanha a ação atribuída ao substantivo "cultura", quando sobre ela nos falam, é "praticar", e não "pensar" a cultura como uma expressão mais ideológica, como para nós: "é preciso praticar a cultura", fulano "não está mais praticando a cultura".

Como já assinalou Melatti (1978), os movimentos e gestos nos amjĩ kĩn são acompanhados de cantos, e os Krahô falam em amjĩ kĩn como se constituindo de canto e dança. Afirmam também os Krahô que seus reper- 
tórios de cantos são os mesmos desde que, em um tempo antigo em que os bichos e plantas "também eram gente", os aprenderam desses seres - bichos e plantas "espiritualizados" são seres a quem os Krahô atribuem uma subjetividade humana, com quem os xamãs podem se comunicar e de quem recebem seus poderes e remédios (MELATTI, 1963). Daí a necessidade que sentem de guardar o conhecimento desses repertórios tal como foram ouvidos da primeira vez, o que exige disciplina e técnicas de memória a serem observadas por aqueles que desejam ser cantadores. Todavia, como sentem que não mais contam hoje com as condições ideais para assegurarem essa memória - que exige o consumo de certo tipo de comida, a abstinência de outras, resguardos, remédios preparados pelos "pajés"e práticas mágicas - os professores krahô veem no registro escrito e audiovisual dos cantos e ritos um recurso à mão para garantir o seu conhecimento pelas gerações futuras e, também com este fim de garantir a memória, estão envidando esforços para a sua introdução nos currículos escolares.

A atenção que dirijo aos cantos krahô aqui foi impulsionada pela necessária problematização da relação entre a ação da escola e práticas culturais krahô, com foco nas implicações da transposição das segundas para o âmbito dos currículos escolares, entendida como oportuna pelos professores krahô. Acresce-se ao meu interesse pelos cantos, dado esse contexto, a afirmação que fazem os Krahô de que não é a escola o que viria a "acabar com a sua cultura", mas acabarem-se os cantadores.

A minha aproximação ao tema dos cantos krahô se deu no contexto de minha interlocução com professores krahô acerca da construção própria da matriz curricular de suas escolas e, especificamente nos anos de 2011 e 2012, no momento em que estávamos às voltas com a elaboração do livro escrito exclusivamente em língua krahô, intitulado Crow kwỳ jarẽn xà (2012) de sua autoria, cujo tema, escolhido por eles, "corridas de toras", trazia inevitavelmente os cantos, alguns deles aqui comentados abaixo. $\mathrm{O}$ texto deste livro me foi traduzido pelos professores que o escreviam, momento em que também registrei outras cantigas e obtive informações sobre sua performance, relações com mitos também por eles narrados e com os ritos. Ressinto-me de formação musical e linguística para refinar as informações prelimiares que trago sobre os cantos krahô neste trabalho. Dados esses limites, apresento, como pano de fundo, informações sobre o entendimento dos Krahô do que seja "oralidade", de processos próprios de aprendizagem, de conhecimento e sobre sua concepção de memória, tomadas no contexto do trabalho com os professores krahô. 


\section{"É TUDO CANTORIA ORAL"}

Para os Krahô os povos se distinguem pelo "jeito":

Se os mehĩ distinguem-se por um lado dos mekarõ, "mortos", e por outro dos kupẽ "estranhos", e pùù-re, "animais", (duas categorias que não admitem ordinariamente a pluralização por me), fazem-no, então, podemos especular, devido à "carne" e ao "jeito" - aos corpos e aos modos de vida - que os caracterizam. (COELHO DE SOUZA, 2001, p. 72).

Esta vinculação entre ser mehĩ (autodenominação dos Krahô em sua língua) e não outro tipo de gente (ou os mortos ou animais) e o que dizem ser o "jeito" krahô se observa, por exemplo, quando indagamos a possibilidade de virem os Krahô, com a intensificação do contato com os não indígenas, a se tornarem como estes últimos: mehĩ não "vira" cupẽ (não indígena), eles respondem, "por causa do jeito de mehĩ manobrar a vivência". Todavia, como também afirmam, se algum krahô estudar muito "vira" cupẽ, "porque não [vai querer] tira[r] mais a roupa, não corre, não dança, não quer ir no mato com os outros, não come comida de mehĩ. Esse "jeito", inclui certamente muitas ações e relações, mas aqui quero ressaltar a ligação com a concepção krahô de "oralidade", já que tenho em foco os seus cantos e rituais. Segundo entendo, para os Krahô a oralidade parece não se restringir à fala, à expressão verbal; a ela parece acoplar-se à experiência corporal. É possível vislumbrar esse caráter quando os Krahô relacionam oralidade e escrita.

Em primeiro lugar, o paralelo entre escrita e educação escolar é claro entre os Krahô, na perspectiva do papel que atribuíram à escola quando esta veio a se instalar no passado em suas aldeias. A ideia de escola e o papel da escola foram pensados inicialmente como o de ensinar a escrita e a leitura. Tanto que a palavra que mais caracteriza o que se faz na escola é ihkàhhôc, que significa escrita, ou palavra escrita. Ihkakê é a palavra que usam para "escrever". Não usam a expressão to ihôko (pintura corporal) para se referirem a "escrever", e possuem outra palavra para "desenhar", que é karõ to. Afirmam que quando se fala em ihkàhhoc imediatamente se sabe que alguém está se referindo a práticas escolares.

Já em alusão à "oralidade", afirmam que é preciso memória para usá-la. Por sua vez, essa memória depende da alimentação certa, que mantenha o "sangue limpo" e a"cabeça leve","só voltada para o mundo krahô". Esclarece uma professora krahô:"essa memória não tem nada a ver com aprender na escola", ela tem a ver, por exemplo, com o resguardo que se faz por ocasião do nascimento 
do primeiro filho e uma série de outros resguardos. Segundo Carneiro da Cunha (1978), há poderes e perigos no sangue que implicam práticas de resguardos, acompanhadas, em todos os casos, de restrições alimentares cuidadosamente categorizadas. Há, ainda, uma "força vital" presa ao sangue. A memória, que também exige tais resguardos, conforme indica a professora krahô, tem a ver, portanto, com práticas que incidem sobre o corpo. Ademais, os "pajés" conhecem uma série de remédios que estimulam essa memória. A mesma professora krahô chamou de "memória da tradição" a uma educação que se realiza fora da escola, que seria diferente da aprendizagem dos conteúdos dentro dela.

Assim, segundo a concepção dos professores krahô, a oralidade e a memória se consolidam naquela que chamaram de "escola da tradição", uma "escola viva", contraposta à "escola morta", que é a que adveio do contato com os não indígenas. De qualquer forma, a presença dos livros didáticos dos cupẽ e seus conteúdos em suas escolas não correspondem, segundo um professor krahô, propriamente à presença da cultura cupẽ entre eles, porque "é só escrita, não é pessoalmente", aludindo a uma concepção de cultura como prática (conforme mencionado acima, amjĩ ton xà, elemento da definição de cultura, é "fazer junto").

Em decorrência, o que se registra por escrito guarda, em parte, esses conhecimentos; mas "é um trabalho de ouvir o que alguém falou, mas [quem ouve] não alcançou o que eles falaram", pois não se pode, a partir da descrição de alguém, experimentar, por exemplo, o "ritmo das danças e cantos". Entendo que nessa experiência corporal resida parte dos dilemas de temporalidade refletidos em propostas alternativas, não oficialmente aceitas, de calendário escolar, que prevejam os tempos rituais krahô. Assim, a escola não se interporia apenas sobre o tempo dos rituais, tal como se supõe quando os indígenas confrontam o cotidiano representado pelo tempo escolar nas suas interrupções do calendário. Diria que se interpõe principalmente a esse tipo de experiência do corpo.

As músicas salvam vidas, defendem os seus corpos com saúde, deixam as pessoas em paz com toda a importância que as músicas levam de acordo com o que cantamos. Algumas delas falam sobre a natureza, fauna, flora e outras detalham cada espécie como: árvore, planta, madeira, folha, galhos, aves, pássaro, pena, bicho, peixe, estrela, rio, mandioca etc. Durante o festival é alegria, feliz, pintura corporal, dança, corrida.

Os professores Krahô, nesta linha, relataram que os amjĩ kĩn e os cantos que Ihes correspondem se vinculam a uma higidez necessária e assegurada 
àqueles que os praticam de forma constante e canônica. Aquele que os desempenha de acordo com o preceito mantém-se "sadio". Cada canto tem a hora certa de ser entoado, que deve ser observada com rigor, sob pena de afetar a saúde do cantador.

Se você errar o horário da música, você mesmo está se acabando. Se cantar certo, vai ser garanhão, sadio, não vai esquecer as músicas. O cantor tem que saber a hora certa. A hora certa é a hora que Krahô aprendeu a música com o bicho. Cada bicho tem seu horário.

O mesmo em relação à pintura corporal:

Cabelo comprido, cortar o corte dos Krahô para ficar bonito na hora da festa, pintar o corpo. Antigamente pintava a qualquer hora. Se saía para o mato, caçada, roça, já chegava ou saía pintado. Por isso eles andavam com saúde e quando corriam não sentiam nada.

Encontrei a afirmação de que hoje, dada a ingestão de alimentos e remédios industrializados e de bebidas alcóolicas, além da não observação rígida de resguardos, o "sangue" dos Krahô estaria poluído, em prejuízo dessa memória. Os cantos são para a saúde, para a alegria, para o bem viver e, também, para a "beleza". Os Krahô dizem que os cantos vêm da natureza, em referência ao fato de terem sido ensinados ou tomados dos animais e plantas no tempo em que esses eram "gente". Obtive de uma professora krahô a observação de que essa "beleza" da natureza só seria apreensível pelos não indígenas caso esses viessem um dia a aprender a língua krahô, ou seja, o seu entendimento por nós não se daria pela mera tradução de seus conteúdos próprios para a língua portuguesa (PECHINCHA, 2011, p. 200). Associo essa observação a outra, feita por uma professora krahô, também sobre os universos linguísticos, que diz sobre o perigo de que poderia estar por advir um momento em que todos falaríamos a mesma língua (como no tempo mítico), no caso o português, que teria mais "força" para dominar as línguas indígenas, e que "esse direito está[ria] forte [hoje] para os jovens". Essas duas observações relacionavam-se à ideia de que o registro escrito dos cantos e a reflexão sobre eles na escola era uma operação imperfeita, mas necessária.

Quando remeto à minha interlocução com os professores krahô em formação na UFG devo ressaltar que não os tomo, nem tomo as suas considerações, como um bloco fechado, pois a experiência na UFG é apenas uma das muitas em que os Krahô estão envolvidos no tocante à educação indígena, à escrita de materiais em língua krahô e ao registro de suas canções. Assim, 
cabe notar, por exemplo, que já existia, na época desta minha interlocução, material publicado escrito por professor krahô, em língua krahô (KRAHÔ; ALBUQUERQUE, 2009) tendo em vista práticas pedagógicas e cuja intenção é o fortalecimento de sua língua, material produzido com a orientação do linguista Francisco Albuquerque, professor da Universidade Federal do Tocantins - Campus de Araguaína.

No que tange especificamente aos cantos, também estes já se incorporavam à experiência de educação indígena, por exemplo, com a participação dos Krahô na Escola Timbira, no programa de educação e referência cultural desenvolvido pelo Centro de Trabalho Indigenista. A sede da Escola Timbira é o Centro Timbira de Ensino e Pesquisa Pënxwyj Hëmpejxà, na cidade de Carolina-MA. O Centro Pënxwyj abriga o Acervo Cultural Timbira, que reúne mais de 400 horas de gravações de cantigas, histórias, conversas, produzidos pelos Timbira, por pesquisadores que estiveram entre os Timbira entre os anos de 1960 e 1980 e, a partir de 1997, com o início do projeto Arquivo Musical Timbira, sob orientação da musicóloga Kilza Setti, estudiosa que já havia realizado pesquisa acadêmica sobre as músicas krahô (SETTI, 1995). Com o "projeto Arquivo Musical Timbira os cantadores Timbira foram incentivados a registrarem suas 'cantorias' para que fossem disponibilizadas no Centro Timbira Pënxwyj Hëmpejxà e intercambiadas entre as diversas aldeias, a fim de que colaborassem para escuta e aprendizado de outros cantadores". (LADEIRA, 2012, obra onde também estão listados os itens do acervo sonoro krahô, p. 152-158). Outra articulação recente dos Krahô, inclusive envolvendo os professores em formação na UFG, se dá sob o "Projeto Banco Sonoro Inkre 'r: registros do universo musical Krahô", coordenado por Verônica Aldé, do Instituto do Trópico Subúmido (ITS) da Pontifícia Universidade Católica de Goiás (PUC Goiás).

Feita esta ressalva em relação às múltiplas articulações dos krahô em torno da educação escolar, de seus ritos e cantos, retomo o momento em que, em nossa interlocução, questionava com os Krahô a entrada desses conhecimentos e práticas na sua escola. Percebi, então, que eles entendiam que se tratava de uma operação de objetivação e representação nova, de uma forma que não faziam antes, de aprofundada discussão e investimento dos professores Krahô em suas práticas pedagógicas, nas quais, como diziam, "não basta hoje apenas realizar os rituais, é preciso conversar com os alunos sobre eles"." "Hoje a escola serve para isso", afirmavam, adicionando um potencial à escola antes não vislumbrado em relação à visão anterior, em que os Krahô entendiam que a escola deveria servir apenas para ensinar a escrita, a leitura 
e operações matemáticas. Certamente, os Krahô independem das escolas ou da universidade para a prática de seus rituais. Todavia, naquele momento em que discutíamos as matrizes curriculares de suas escolas, os professore krahô em formação na UFG advertiam sobre um acréscimo de estímulo aos ritos e cantos, por meio de suas práticas pedagógicas. No mesmo sentido, observei o seu intuito de repensarem e refazerem, ou melhor, construírem eles mesmos, pela primeira vez, os seus currículos escolares, tomando as festas e o que estas trazem de ensinamentos corporais, de relações intersocietárias, de significados cosmológicos, de ética e de estética como eixo em torno do qual se conformaria um modelo de escola krahô. Enfim, pude observar que eles reconhecem na transposição desses conhecimentos e práticas para a escola, uma ruptura com o sistema da oralidade, mas não se acanham em perceber a sua conveniência para a manutenção dessas práticas. Afinal, os tempos são outros, não se trata de "voltar para ser como krahô velho, mas [ter] outra cara como Krahô".

Estudar sobre a música, sobre a história. Chamar um mais velho. Os alunos fazem texto sobre o que entenderam.

Quem ensinou a música para os Krahô é macaco, xexéu, arara, peixe. Tem menina que é boa de pintura, faz banner. Tudo é fora da sala de aula, mas é o momento de trazer para a sala de aula também. Por causa da escrita. Não é só no pensamento. Quando ele [o jovem] fica ouvindo aqui [na escola], [depois] vai para o pátio e já sabe, aumenta o interesse dele, porque entende essas músicas. Até que vai entender tudo e todo mundo sabe aquela música e vai cantar, a cantoria fica forte.

O pátio é lugar de práticas rituais e das reuniões cotidianas dos Krahô. Localiza-se ao centro da aldeia, cuja forma é redonda. Do pátio saem caminhos radiais que desembocam no caminho circular em torno do qual se dispõem as casas. O professor continua: "quando o jovem ouve as músicas na escola, quando ele não sabe cantar, acalma. A escola nos dias de hoje não é para isso?" Aqui se refere a um dos entendimentos que demonstrava ter, naquele momento, a respeito e valorização da tradição indígena preconizada pelas normas da educação escolar indígena. E, traçando uma linha de relação entre o que acontece na escola e fora dela, na aldeia, e já transpondo um limite que na realidade não existe e não deve existir, o mesmo professor prossegue: “Não morreu ainda não, está equilibrando, a escola ajuda, no futuro ajuda. $\mathrm{O}$ aluno tem que aprender na escola e procurar quem conta no krĩ [aldeia] para confirmar, aprender pessoalmente". 
Para se ter uma noção da performance ritual krahô e da importância dos cantos, sigo indicando alguns de seus elementos essenciais. Transcrevo, ainda, alguns cantos rituais, conforme ditados e traduzidos para o português por professores krahô, para apontar recursos estilísticos e implicações cosmológicas, mutuamente ligados. É possível, a partir dessa transcrição, se ter uma ideia do entendimento e relacionamento dos Krahô com seres do que chamamos de natureza e sobrenatureza e, portanto, além da diferença da forma pedagógica, a diferença epistemológica em relação aos conteúdos da escola dos não indígenas.

\section{OS CANTOS E GESTOS}

Em “Nota sobre a música Krahô", Melatti fornece informações sobre quem canta, a forma de se entoar os cantos, os locais, os momentos, os instrumentos musicais e procedimentos mágicos para se garantir um bom desempenho ao cantar. Há, entre os Krahô, cantos associados a rituais e outros que podem ser entoados fora deles. Os primeiros podem ser entoados na praça ou nos caminhos da aldeia, por um só indivíduo ou em grupo, por homem ou por mulher, parado ou em movimento. Os segundos podem ser cantados na praça, nos caminhos ou nas casas (MELATTI, 1982).

A palavra krahô para música é increr. Os Krahô dizem que increr é qualquer música, entoada em qualquer festa. A música tocada nos forrós (a expressão que usam na língua krahô para a festa de forró é amjĩ kĩn catea = muito movimento), que apreciam e promovem com frequência, também é increr, ainda que as músicas sejam, mesmo composta por eles, cantadas em português e ao estilo do forró regional. Dizem também que as músicas krahô são classificadas segundo os ritos: a música da festa da batata (jàt) é yàt increr. A música da festa do milho (põhy) é põhy increr. Obtive palavras que significariam o conjunto das músicas dessas festas: assim cahĩjê seria "o conjunto de músicas só da batata" e hepoy"o nome geral para o conjunto das músicas do milho".

São muitas as técnicas que usam ou usavam para o aprendizado, a memória e o bom desempenho nos cantos. Conforme o relato de um professor krahô:

Preparar o cérebro para arquivar as cantigas, usar o cérebro de um passarinho chamado canarinho pànrãjre (canarinho), pêhàre (xexéu), awxêt (tatu peba). Pode-se matar alguns desses sujeitos e tirar o cérebro e passar nos ouvidos, de manhã, durante uma semana, bem cedo de manhã, enquanto ainda não alimentou nada, vazio, para poder a memória ficar leve para gravar 
imediatamente as músicas e outrossim melhorar as vozes utilizando o pomo-de-adão do guariba, usar o popoc (cano de cana-juba do brejo) ou comer a terra do oco da árvore que se chama kràcre (pau-terra), isso limpa a garganta para não explodir a voz quando cantar durante a noite até de manhã. Esta é a receita natural de bem para facilitar as vozes bonitas dos artistas krahô.

Melatti (1980) descreve uma série de cuidados e materiais usados pelos Krahô para assegurarem a acuidade auditiva necessária ao aprendizado dos cantos e para regularem o tom da voz.

É curioso que os Krahô se refiram ao cantador, figura imprescindível em seus ritos, sempre na forma masculina (hokiehkatê). As mulheres que o cantador convoca para cantar no pátio, e que cantam sempre juntas, em coro, são hõkrepoj (LADEIRA, 1982, p. 8). Segundo Melatti (1982), todas as cantadoras são chamadas hõkrepoj e usam um distintivo, uma faixa de algodão, como um talabarte. Ouvi a notícia de uma moça com cerca de 15 anos de idade que havia recentemente recebido uma dessas faixas, por ser uma notável cantora. O maracá é um acessório indispensável ao cantador que canta regendo o coro das mulheres, dispostas uma ao lado das outras, no pátio, ou seguido por mulheres e homens pelo caminho circular da aldeia, tais como os que aqui transcrevo. Nessas cantorias, cantam o cantador e as mulheres, jovens e mais velhas. Os rapazes não cantam, mas acompanham dançando, atrás do cantador, com passos seguindo o movimento do cantador que se desloca ao longo da fila de mulheres e para frente e para trás. Ouve-se, de vez em quando, o soar de pequenas buzinas de cabaça, com sua música própria, não coordenada com a do cantador e cantoras. Ouve-se também, quando o ritmo da música se acelera e todos aparentam um estado de grande excitação, a voz de um ou dois cantores individuais, entoando um canto também desencontrado ao do cantador principal e cantoras. O cantador com o maracá despende uma enorme energia, seja pelo tom de sua voz, seja por sua dança que vai se tornando cada vez mais apressada. Não é sem razão os cuidados que tomam para aperfeiçoar e não deixar a voz "estourar" enquanto cantam. As mulheres, lado a lado, com suaves movimentos dos braços e flexionando levemente os joelhos, cantam uma mesma estrofe até o fôlego findar. $O$ canto das mulheres é a repetição do mesmo verso e melodia entoada pelo cantador.

Evidencia-se nas cantigas abaixo transcritas - como em toda composição que recolhi - a ocorrência de microparalelismo, certamente redundância a serviço da melodia em um canto em que a composição poética se faz com dois ou três versos. Repete-se o verso inteiro ou apenas parte de um verso. O número de repetições de um verso varia entre as composições, isto é, não existe uma 
forma fixa para todas elas. Já a sequência de cantos é sempre fixa: tal como não se cria cantos novos, também não se altera a sequência em cada sessão de cantos. Há momentos certos para se entoar cada sequência de cantos. Há cantos que só podem ser cantados em determinados momentos do dia ou da noite, e há cantos que só o podem ser no ano em que se realiza determinado ritual que lhe corresponde. Mesmo na escola, só se cantam esses últimos no ano e mês certos.

A experiência prática, vivencial, corporal da "oralidade" que na performance acima assinalada é um aspecto que aqui se quer destacar, posto que imediatamente vinculado ao movimento articulado pelo canto e que os próprios Krahô enfatizaram. Todavia isso significa reduzir o cenário dos eventos musicais krahô, tal a complexidade dos ritos krahô na sua multifacetada expressão, patente na minuciosa descrição que deles fez Melatti e em seu esforço para nos orientar na intrincada malha tecida nos ritos, que envolvem nomes e personagens, consanguinidade e afinidade, diversos pares de metades, relações de gênero, classes de idade, mitologia, tempo e espaço. Por outro lado, no seu livro sobre os ritos, encontramos inúmeras descrições sobre o momento e o local nos quais se canta e sobre quem está cantando, mas poucas transcrições de letras de cânticos. Vou me deter sobre a transcrição de alguns cantos, obviamente reconhecendo a deficiência de não poder fazê-lo em consonância com a miríade de ritos krahô e nem mesmo com um rito completo. De qualquer forma, em princípio, o cotejamento que fiz entre os cantos que recolhi e os ritos descritos por Melatti, confirmam a observação já feita pelo autor de que

... os cânticos parecem manter uma certa relação com os movimentos e gestos do rito, mas essa relação não é direta. Ela se faz por meio de alusões vagas, modificadas por figuras poéticas difíceis de se compreender e pelo arranjo estético dos sons." (MELATTI, 1978, p. 16).

O que o conjunto de cantos que recolhi, bem como a amostra que transcrevo abaixo, por ora me permite algumas considerações sobre os seus conteúdos. Destaco, sobretudo, neles, a ocorrência de um ato musical em que o locutor canta o canto de um "bicho" ou um espírito que, por sua vez, está "imitando" outros "bichos", sugerindo que há um ponto de vista outro que o do cantador que intermedeia, com a musicalidade, o conhecimento do comportamento desses outros. Assim, há duas entidades distintas dos cantadores presentes no canto: o "bicho" que ensinou a música e o "bicho" que ele descreve. Esta operação está presente em todos os cantos, como se verá. Nela, o cantador não está ele mesmo diante da cena que canta, como o xamã/cantador nos cantos xamânicos de outros povos indígenas descritos 
por Cesarino (2006). Não há, igualmente, entre os Krahô, o tipo de contato intensivo, em que quem canta experimenta o sentido e o devir do espírito/ bicho cantado, descrito por Tungy entre os cantadores e os "povos dos cantos" entre os Maxacali (TUNGY, 2009).

Ao indagar sobre a possibilidade da relação entre amjĩ kĩn examanismo, os Krahô dizem se tratar de práticas de caráter distinto. Como explicam os Krahô "o que a 'pajelança' faz não tem nada a ver com dança". Por seu turno, o "pajé", em sua ação de cura, não canta, embora possa haver também "reza" em ritos, "mas não é em qualquer festa". A este respeito, por exemplo, os professores krahô falaram-me sobre um canto entoado na praça, no escuro, por pessoas que possuem certos nomes, em ocasiões onde se está realizando o tratamento xamânico de alguma doença ou mal que acomete algum ou alguns indivíduos. $\mathrm{O}$ "pajé" pode se juntar a esse grupo de pessoas na praça, mesmo que não possua nome pertencente ao grupo. Alguns desses nomes são: Hàrhê, Xôkã, Tejapoc (nomes de homens) e Kencaprêc (nome de mulher ou de homem). Essa e outras informações relativizam a anterior afirmação da separação entre os domínios do xamanismo e dos amjĩ kĩn, tal como uma música "secreta" ensinada pelo "chefe da batata", e que se canta por ocasião da "festa da batata" (Jàt jõ pĩ), e só nesta festa, quando, ao final do rito, se vai cortar a tora que o finaliza, na mata. Com essa música, se pede para a tora não machucar os corredores, para que lhes pareça leve e que não caia durante o percurso da corrida. Falam também sobre o perigo que cerca as crianças nos ritos de iniciação, momento no qual os espíritos dos mortos rondam a aldeia e o pátio, querendo capturá-las. Atribuem também um caráter "sagrado" à machadinha de pedra Khoiré, providencial em toda cantoria, pois pode ajudar a lembrar todas as músicas. Como dizem, "Khoiré é uma coisa inteligente, sábia".

Os Krahô afirmam estar repetindo uma cantiga tal como lhes foi ensinada pela primeira vez no tempo mítico e dizem que as cantigas descrevem o comportamento dos bichos ${ }^{3}$. Quando relatam o tipo de experiência que têm com o canto e a dança, essa se aproxima do que entendemos como lúdico ("faz alegrar, para curtir, dançar") e estético: é a "beleza" da natureza que estão cantando, uma beleza que gera "emoção" naqueles que podem entender o seu significado, como os mais velhos - interessa notar que nem todos os que cantam entendem o que estão cantando, o que ressalta a performatividade, a importância que atribuem a experimentar e conhecer o seu ritmo.

Seeger (1980) já identificara entre os Suyá esse acoplamento entre som e movimento, a mesma palavra suyá ngre usada para significar cantar e/ ou dançar (p. 85). Também entre os Suyá, tanto as akia (um dos dois gêneros de 
música suyá), assim como "muitos ngere", são aprendidos de animais e plantas, mas Seeger constatou o aprendizado de novos ngere nos períodos rituais e distinguiu os ngere "antigos", transmitidos aos Suyá no passado mítico e os novos ngere, cuja data de introdução é sempre lembrada. Interessa para a comparação que faço aqui a observação de Seeger de que "entretanto não se dá muita importância ao processo de composição, porque é um animal, planta ou abelha que está cantando a canção; o compositor é simplesmente um mediador que aprende a canção e então a ensina ao resto dos homens" (SEEGER, 1980, p. 99). É para esse aspecto particular dos cantos que quero principalmente chamar a atenção, pois parece jogar papel determinante na poética krahô.

Sobre as duas sequências maiores de cantos que transcrevo abaixo, a primeira me foi fornecida como entoada por ocasião dos rituais de investidura e abdicação das crianças wỳhtỳ. A casa Wỳhtỳ é importante local ritual, onde mora a criança wỳhtỳ, uma menina ou um menino, associados, respectivamente, a todos os homens adultos e meninos e a todas as mulheres adultas e meninas da aldeia. A casa é livremente frequentada por todos da aldeia e por visitantes, e tais crianças são como parentes de todos (MELATTI, 1978, p. 302-329). Já a segunda sequência, corresponde ao conjunto de cantos entoados à tarde por ocasião da transferência da administração da aldeia Cachoeira pelos membros da metade Katamjê aos da metade Wakmẽjê (metades sazonais, do inverno e do verão, respectivamente), no final de abril de 2011, a que tive oportunidade de assistir. Os cantos dessa segunda sequência podem ser cantados em qualquer ocasião festiva, não pertencem a um rito específico.

As duas sequências são cantadas pelo cantador com maracá, em conjunto com as mulheres, na praça e no caminho circular em volta da aldeia. Sobre o rito wỳhtỳ, um professor Krahô explicou:

Toda comunidade combina e escolhe uma criança, pode ser menino ou menina. Todos vamos lá e vamos pedir para o pai da criança e se ela pode ser wỳhtỳ. Se o pai quer, então vão combinar. No outro dia vão caçar e vão chegar perto da aldeia, colocar carne na vara [o professor faz referência ao "pau de carne" conforme Melatti abaixo], correr com a tora, cantar com a criança na porta da casa dela. Tem Seriema no meio do pátio, que vem gritando até chegar no menino ou menina wỳhtỳ.

No que tange ao rito wỳhtỳ, Melatti precisou procurar em outros dois mitos, além daquele de origem desse rito, os sentidos dos objetos rituais e dos personagens nele presentes, de forma que o mesmo parece articular-se a 
referências múltiplas: por exemplo, o personagem Seriema e o"pau de carne" disputado pelas mulheres no rito wỳhty evocam o mito onde as seriemas cortaram a vulva de uma moça virgem e a penduraram em varas, das quais surgiram as mulheres (1978, p. 302-329). Da mesma forma, o complexo de imagens evocadas nos cantos que transcrevo deste rito nem sempre são identificáveis como compondo a cena do mito associado, embora outros sim. Todavia, não é possível afirmar que os cantos constituam peças autônomas, já que há uma classificação krahô para os cantos de acordo com os ritos, a não ser os que podem ser entoados em qualquer ocasião festiva.

Passemos, então, à sequência de wỳhtỳ. Embora o mito de wỳhtỳ que os Krahô me contaram, diga que o rito foi encenado pela primeira vez pelos pássaros e que foram os pássaros que ensinaram o wỳhtỳ, ouvi de alguns professores krahô que "quem ensinou a cantoria do wỳhtỳ foi Cupẽkrãjakrôre". Melatti transcreveu duas versões do mito de Cupẽkrãjakrôre como compondo o conjunto de mitos que explicam a origem dos cantos (2010, p. 34). Trata-se de um ser que, no tempo mítico, segundo os professores krahô, "era igual gente, vivia dentro do cupim e conhecia a música de todos os bichos". Os seis primeiros cantos da sequência são cantados por Cupẽkrãjakrôre e todos, exceto a quinta, descrevem o comportamento de pássaros. Deles, destaco o canto 3 , com seu fino jogo de perspectivas. Neste canto, Cupékrãjakrôre canta que o papagaio conta sobre a sua fala (do papagaio) "para mim". Com a tradução com que conto, não é possível saber se Cupẽkrãjakrôre é um intermediário ou um narrador, mas suscita esta indagação. $O$ conceito de perspectivismo refere-se à afirmação bastante generalizada entre os povos ameríndios de que os animais são gente, ou se veem como pessoas. Fundamenta-se no entendimento indígena de uma base comum humana para humanos e animais (e também a vegetais ou minerais, como entre os Krahô), ao contrário do que pensam os ocidentais, que atribuem uma base biológica comum para humanos e animais, e a humanidade só aos humanos. Retenho aqui, o que implica da capacidade de capturar ou sentir os pontos de vista e afecções de outros seres (VIVEIROS DE CASTRO, 1996). Em todos os cantos abaixo, nota-se ora que um bicho que canta descreve o comportamento de outro bicho, ora que um bicho canta o canto de outro bicho - ou como se fosse o outro bicho.

Ressalvo que a tradução das estrofes das cantigas com que conto não permite o perfeito entendimento do que se passa na cena cantada pelo bicho. Por sua vez, os/a professores krahô explicam que às vezes não é possível uma tradução literal por eles do que está sendo dito nas cantigas e que há inclusive músicas sem significado, como dizem, é só "oralidade". 


\begin{tabular}{|c|c|c|}
\hline Canto 1: & Canto 2: & Canto 3: \\
\hline Tije tije hê & Hahĩ hêê hahĩ hahĩ & Hĩ mã crỳre \\
\hline Tije tije hê & Hêêê hahĩ & Hĩ mã crỳre \\
\hline Tije tije hê & Hêêê hahĩ & Hĩ mã crỳre \\
\hline Tije tije hê & Hahĩ hêê ja cwỳrỳ cwỳc re & Hĩ mã crỳre \\
\hline Tije tije hê & ri cuwa nã pari to mõre & Hĩ mã crỳre \\
\hline Tije tije hê & Tradução: & Hĩ mã crỳre \\
\hline $\begin{array}{l}\text { Tije tije hê mã xàj caxàc } \\
\text { cà krã kãm mã gũjapy }\end{array}$ & $\begin{array}{l}\text { Quem canta é Cupẽkrãjakrôre, } \\
\text { cantando como o passarinho ja }\end{array}$ & Hĩ mã crỳre \\
\hline Teretete mã wàri cre japỳhỳ & cwyry cwýc re anda sobre a lama. & Hima cryre \\
\hline Tradução: & $\begin{array}{l}\text { ja cwỳry cwỳc re = passarinho } \\
\text { que só desce na época da chuva }\end{array}$ & $\begin{array}{l}\text { hi ma cryre xa ca ca } \\
\text { himã haca côcô }\end{array}$ \\
\hline $\begin{array}{l}\text { Quem canta é Cupẽkrãjakrôre, } \\
\text { cantando que o pica-pau } \\
\text { está no oco do pau e em sua } \\
\text { cabeça (do pica-pau) tem } \\
\text { um penacho tremendo. }\end{array}$ & cuwa = barro, lama & $\begin{array}{l}\text { Jarẽrẽ } \\
\text { Tradução: } \\
\text { Quem canta é Cupẽkrãjakrôre, } \\
\text { cantando que "o papagaio conta }\end{array}$ \\
\hline Tije = mostrando & & hĩ mã = para mim \\
\hline xàj = pica-pau & & crỳre = papagaio \\
\hline krã kãn = na cabeça & & xà ca ca = você está \\
\hline gũjapy = penacho & & haca côcô = fala \\
\hline teretete $=$ tremendo & & jarẽrẽ $=$ contar \\
\hline $\begin{array}{l}\text { mã wàri cre japỳhỳ = } \\
\text { no oco do pau }\end{array}$ & & \\
\hline $\begin{array}{l}\text { Jahy hyyy xô xô xô xô xô ỳỳy } \\
\text { (som emitido para marcar o } \\
\text { intervalo entre as músicas) }\end{array}$ & & \\
\hline
\end{tabular}

\section{Essas três primeiras músicas da sequência são cantadas em ritmo} lento. As três seguintes, em ritmo acelerado.

\begin{tabular}{|c|c|c|}
\hline $\begin{array}{l}\text { Canto 4: } \\
\text { Prỳ mã jacaré } \\
\text { Prỳ hỳ mã jacaré gõ hõ wỳrỳỳỳ } \\
\text { Hỳ prỳ mã jacaré } \\
\text { He mã hatoro re mãããa } \\
\text { mã hatoro re mããã } \\
\text { Tradução: } \\
\text { Quem canta é Cupẽkrãjakrôre, } \\
\text { cantando que o lambuzinho, } \\
\text { que tem penas brancas, } \\
\text { está caminhando em } \\
\text { direção à comida. } \\
\text { hatoro re mã = lambuzinho } \\
\text { prỳ = pena } \\
\text { jacaré = branca } \\
\text { gõ = comida } \\
\text { gõ hõ wỳrỳỳỳ = caminhando } \\
\text { no rumo da comida }\end{array}$ & $\begin{array}{l}\text { Canto 5: } \\
\text { Hê pêcrowati jarê cã mã } \\
\text { ri têre haricwa há jarẽ } \\
\text { Hê pêcrowati jarê cã mã } \\
\text { ri têre haricwa há jarẽ } \\
\text { He mã hari cwa há jarẽ hẽẽẽ } \\
\text { hari cwa há jarẽ hẽẽẽ } \\
\text { jarê cã mã ri têre haricwa hà jarẽ } \\
\text { Tradução: } \\
\text { Quem canta é Cupẽkrãjakrôre, } \\
\text { cantando que embaixo } \\
\text { da raiz do buriti a ariranha } \\
\text { está contando a sua fala/ } \\
\text { língua/música. } \\
\text { pêcrowati = buriti } \\
\text { jarê = raiz } \\
\text { têre = ariranha } \\
\text { haricwa ha = fala, língua, } \\
\text { música da ariranha } \\
\text { jarẽ = contando }\end{array}$ & $\begin{array}{l}\text { Canto 6: } \\
\text { He he jure hỳỳỳ } \\
\text { hỳre he } \\
\text { hỳ wê cãre } \\
\quad \text { wê cãre } \\
\text { Tradução: } \\
\text { Quem canta é Cupẽkrãjakrôre, } \\
\text { perguntando onde está a curica. } \\
\text { cãre = curica }\end{array}$ \\
\hline
\end{tabular}


A sequência de cinco cantos do wỳhtỳ que se inicia abaixo só se canta pela manhã, no período das $7 \mathrm{~h}$ às $10 \mathrm{~h}$. Essas músicas não se cantam com o maracá. Um cantador sozinho as entoa andando em volta do círculo da aldeia. $O$ canto 10 é entoado em ritmo lento (caprĩ), os cantos 7, 8, 9 e 11 o são em ritmo acelerado (huphê, hupitê). É o Macaco (Cukôj) que canta essas músicas, "só o Macaco, imitando os outros bichos". São cukôj crer (música do macaco). Interessa notar que Macaco é um personagem no rito wỳhtỳ que fica na praça zombando das onças, outros personagens, que percorrem o círculo da aldeia parando em frente às casas, rosnando. Dos cinco cantos destaco o canto 9, onde Macaco canta, como se fosse a arara, que olha o papagaio ao longe; e o canto 11 onde Macaco "imita o ritmo do grito da seriema que canta na chapada". O personagem Seriema no rito wỳhtỳ também grita (não canta) imitando o barulho das seriemas.

\section{Conforme me explicou um professor Krahô:}

Macaco está imitando o gato-do-mato e a seriema, porque ele é um bichinho esperto para saber todos os cantos e ensinar mehĩ. Todos os dias os macacos cantavam em cima da serra e os mehĩ foram lá e entenderam.

\begin{tabular}{|c|c|c|}
\hline $\begin{array}{l}\text { Tire tire he hô hã ra } \\
\text { cwỳ cã mã hã ratẽ } \\
\text { Hê nẽ hô hô pànà hè } \\
\text { tire jarô hô hã } \\
\text { hô hô pànà hè tire jarô hô hã } \\
\text { Racwỳ cã mã hã ratẽ } \\
\text { Hê } \\
\text { Tradução: } \\
\text { Quem canta é Macaco, cantando } \\
\text { que está criando uma arara, mas, } \\
\text { infelizmente, ela está seguindo } \\
\text { outras araras. A arara está } \\
\text { voando, subindo e descendo. } \\
\text { ra cwỳ = acompanhando } \\
\text { ratẽ =junto } \\
\text { pànà = arara } \\
\text { jarô = para cima } \\
\text { cã mã hã ratẽ = está no } \\
\text { meio (de outras araras) }\end{array}$ & $\begin{array}{l}\text { Canto 8: } \\
\text { Hija wỳrỳ tire he hô hô hô hããã } \\
\text { Hija wỳrỳ tire he hô hô hô hããã } \\
\text { Hija wỳrỳ tire he hô hô hô hããã } \\
\text { Xá pê cagã hã tyc cytê pyránẽ } \\
\text { Pêwa tyc cy to tẽẽ } \\
\text { Xá pê cagã hã tyc cytê pyrànẽ } \\
\text { Pêwa tyc cy to tẽẽ } \\
\text { Tradução: } \\
\text { Quem canta é Macaco, cantando } \\
\text { que a cor da casca do besouro se } \\
\text { assemelha à cor preta da cobra. } \\
\text { hija wỳrỳ tire = casca do besouro } \\
\text { cagã = cobra } \\
\text { tyc cy = preta } \\
\text { pyrànẽ = parece }\end{array}$ & $\begin{array}{l}\text { Canto 9: } \\
\text { Hãhê hãhê hãhê hãhê hêêê } \\
\text { Hãhê hã hêêê } \\
\text { Hãhê hãhê hãhê hãhê hêêê } \\
\text { Hãhê hã hêêê } \\
\text { Hãhê hã hêêê hêêê } \\
\text { He pànà tite xãmũ cãmã } \\
\text { pànà tite xãmũ cãmã crỳre pupu } \\
\text { Tradução: } \\
\text { Quem canta é Macaco, } \\
\text { cantando, como se fosse a arara, } \\
\text { que olha o papagaio ao longe. } \\
\text { pànà tite xãmũ cãmã } \\
\text { = arara grande } \\
\text { crỳre = papagaio } \\
\text { pupu = olhar }\end{array}$ \\
\hline
\end{tabular}




\begin{tabular}{|l|l|}
\hline Canto 10: & Canto 11: \\
Ropoore watari & Hôô hôô hôô hôô hôô hôô \\
Ropoore watari & Hôô hôô hôô hôô hôô hôô \\
Ropoore watari & Hôô hôô hôô \\
Ropoore watari & Hôô hôô pjêc quê re \\
ri ita jacot tô na \\
Ropoore watariii & Hacàrà to ramjĩ to hôô hôô hôô \\
Ropoore watariii wàri & Tradução: \\
cô cape nã riii & Quem canta é Macaco, imitando \\
Mãropoore xapi xapiii & o"ritmo do grito da seriema \\
hê hê watari & que canta na chapada". \\
Tradução: & hôô hôô hôô hôô hôô hôô \\
Quem canta é Macaco, & som do grito da seriema \\
cantando que o gato-do-mato & pjêc quê re ri = aquela seriema \\
está andando na margem do & mato, procurando caça. \\
ropore = gato-do-mato & ita jacot tô na = canta \\
(gato-maracajá) & naquela chapada \\
watari = aquele lugar & hacàrà to ramjĩ to = \\
wàri cô cape nã ri = beirando & o ritmo do grito \\
a margem do mato & \\
xapi xapi = procurando caça & \\
\hline
\end{tabular}

A seguir, apresento uma sequência de dez cantos, todos entoados por ocasião da transmissão da administração da aldeia. $O$ canto 1 pertence à categoria inkrerjitô ("música para juntar o povo"). O cantador começa sozinho, com o maracá, estimulando as pessoas a virem para o pátio cantar juntas. Seu ritmo é lento. Todas são músicas cantadas pelo pássaro xexéu (pêhàre). Destaco o canto 2, onde Xexéu "está sentado na minha frente e está sorrindo para mim, como o macaco, contando o jeito como o macaco sorri".

\begin{tabular}{|c|c|c|}
\hline $\begin{array}{l}\text { Canto 1: } \\
\text { Hê japy mã jaje } \\
\text { mã jaje he } \\
\text { Pique he re japy } \\
\text { mã jaje } \\
\text { mã jaje } \\
\text { Tradução: } \\
\text { Quem canta é Xexéu, contando } \\
\text { que o esquilo está falando: } \\
\text { "este aqui é meu rabo". } \\
\text { mã jaje = meu rabo } \\
\text { piquere = esquilo }\end{array}$ & $\begin{array}{l}\text { Canto 2: } \\
\text { Ihi cu nã mã rê jỹnẽ } \\
\text { Hê na cuxa ha } \\
\text { Cucore jarẽnẽ } \\
\text { Tradução: } \\
\text { Quem canta é Xexéu, que } \\
\text { está sentado na minha frente } \\
\text { e está sorrindo para mim, } \\
\text { como o macaco, contando o } \\
\text { "jeito" como o macaco sorri. } \\
\text { ihi cu nã mã = voltado para mim } \\
\text { jỹnẽ = sentar } \\
\text { na cuxa ha = sorri (para mim) } \\
\text { cucore = macaco } \\
\text { jarẽnẽ = na minha frente }\end{array}$ & $\begin{array}{l}\text { Canto 3: } \\
\text { Pootê wa jo mã nã nã mõ } \\
\text { Hê pootê hê } \\
\text { Pootê wa jo mã nã nã mõ } \\
\text { Hê pootê hê } \\
\text { Mã gĩjaxy têêrê } \\
\text { Mã gĩjaxy têêrê pootê hê } \\
\text { Tradução: } \\
\text { Xexéu está cantando que o } \\
\text { veado campeiro joga a perna } \\
\text { para trás, mas é o veado mateiro } \\
\text { que faz assim, não o campeiro. } \\
\text { pootê = veado campeiro } \\
\text { wa jo mã nã nã mõ = } \\
\text { jogando a perna para trás } \\
\text { gĩjaxy = veado mateiro }\end{array}$ \\
\hline
\end{tabular}




\begin{tabular}{|c|c|c|}
\hline $\begin{array}{l}\text { Canto 4: } \\
\text { Hixô prarê } \\
\text { Hixô prarê } \\
\text { Hixô prarê prarê } \\
\text { Hixô prarê prarê } \\
\text { Rê prarê rê pànà crỳtỳre } \\
\text { Tradução: } \\
\text { Xexéu está cantando que a } \\
\text { arara de penas bonitas está } \\
\text { roubando as suas frutas. } \\
\text { hixô prarê = fruta } \\
\text { pànà = arara } \\
\text { crỳtỳre = penas bonitas }\end{array}$ & $\begin{array}{l}\text { Canto 5: } \\
\text { Hõõrêê, hõrê, hõrê, hõrê } \\
\text { Hõõrêê, hõrê, hõrê, hõrê } \\
\text { Ri cààcà caxàcàre haricwa nã } \\
\text { Hõ hy jacare } \\
\text { Tradução: } \\
\text { Xexéu está cantando que a } \\
\text { jandaia está bicando a fruta e } \\
\text { sujando o bico de branco. } \\
\text { hõrê = bicando (frutas) } \\
\text { cààcà caxàcàre = } \\
\text { jandaia (pequena?) } \\
\text { haricwa nã = no bico } \\
\text { jacare = branco } \\
\text { hõ hy jacare = sujando de branco }\end{array}$ & $\begin{array}{l}\text { Canto 6: } \\
\text { Wajũca rããti cãmã pypa ha nõ } \\
\text { Wajũca rããti cãmã pypa ha nõ } \\
\text { jũca rããti cãmã pypa ha nõ } \\
\text { Crĩ hi tajê mã } \\
\text { Crĩ hi tajê mã } \\
\text { Tradução: } \\
\text { Xexéu canta que mais de } \\
\text { quatro aldeias estão limpas. } \\
\text { wajũca rããti = lugar limpo, } \\
\text { o círculo da aldeia } \\
\text { cãmã pypa ha nõ = aquele que } \\
\text { está cantando está no limpo } \\
\text { crĩ hi tajê mã = mais } \\
\text { de quatro aldeias }\end{array}$ \\
\hline $\begin{array}{l}\text { Canto 7: } \\
\text { Cuwêni caxàcà tê hê } \\
\text { Cuwêni caxàcà tê hê } \\
\text { Cuwêni caxàcà tê hê } \\
\text { Raw caati hi cunõ hõ } \\
\text { Ate wyry wyty } \\
\text { Tradução: } \\
\text { Xexéu canta que o pé do } \\
\text { passarinho grande está apoiado } \\
\text { e se mexendo no galho limpo. } \\
\text { cuwêni = passarinho "comum" } \\
\text { caxàcà tê hê = grande } \\
\text { raw caati = galho limpo } \\
\text { cunõ hõ = pousado } \\
\text { ate wyry wyty = pé do } \\
\text { passarinho mexendo }\end{array}$ & $\begin{array}{l}\text { Canto 8: } \\
\text { Hê xà pooho ri jacrô hô hô } \\
\text { Hô pori jacrô hô hô } \\
\text { Japê hààti jõ hôôtô ri jacrôhôhô } \\
\text { Japê hààti jõ hôôtô ri jacrôhôhô } \\
\text { Hô pori jacrô hô hô } \\
\text { Tradução: } \\
\text { Pehàti (xexéu grande) } \\
\text { canta que mexe o peito } \\
\text { para tirar a sujeira, o pó. } \\
\text { hê xà pooho ri = o que } \\
\text { está cantando } \\
\text { jacrô = sujeira } \\
\text { japê hààti = xexéu grande } \\
\text { jõ hôôtô = peito } \\
\text { ri jacrô = mexendo }\end{array}$ & $\begin{array}{l}\text { Canto 9: } \\
\text { Hê jahire hê hara ponẽ } \\
\text { Jahire hê hara ponẽ } \\
\text { Jahire hê hara ponẽ } \\
\text { Jahire hê hara ponẽ } \\
\text { Jahire ri wapucôô côtôri } \\
\text { Jahire ri wapucôô côtôri } \\
\text { Hara ponẽ } \\
\text { Tradução: } \\
\text { Xexéu canta que (ele?) abre } \\
\text { a asa e com a asa fininha } \\
\text { vai enfrentar a mata. } \\
\text { jahire hê = fininha } \\
\text { hara = asa } \\
\text { ponẽ = abrindo } \\
\text { wapucôô côtôri = mata }\end{array}$ \\
\hline $\begin{array}{l}\text { Canto 10: } \\
\text { Hê haruwaja hê hê hê hê ruwaja } \\
\text { Haruwaja hê hê hê hê ruwaja } \\
\text { Hê crẽtire rê hê crẽtire rêê } \\
\text { Haruwaja, haruwaja hê hê hê } \\
\text { Tradução: } \\
\text { Xexéu canta que o periquito } \\
\text { tem mais habilidade do que ele } \\
\text { para voar (quando está no mato } \\
\text { e não esbarra nas árvores). } \\
\text { haruwaja = habilidade } \\
\text { crẽtire = periquito }\end{array}$ & & \\
\hline
\end{tabular}


Na sequência acima, o ritmo se acelera a partir do canto 4.

Transcrevo abaixo duas cantigas, cantadas por ocasião do rito da colheita do milho. Na primeira parte - canto 1 - Lambuzinho canta imitando a arara e, na segunda - canto 2 - canta "com sua própria pessoa"; postura que não é possível perceber na tradução das palavras e expressões.

\begin{tabular}{|l|l|}
\hline Canto 1: & Canto 2: \\
Harara harara mõ hỳ hỳ & Pyyty te rũmu ri pànã rãre \\
Harara harara mõ hỳ hỳ & Càrà to pra haha \\
Harara japànà rãã tê hê japy hy & Pyyty te rũmu ri pànã rãre \\
japànà rãã tê hê japy hy & Càrà to pra haha \\
Harara... & Hatoro hatoro re he he he \\
Tradução: & Hatoro hatoro re he he he \\
Quem canta é Lambuzinho (Ahtorore), imitando & Pyyty te rũmu... \\
a arara: a asa faz movimento e barulho, o & Tradução: \\
rabo azul e amarelo da arara canindé. & Quem canta é Lambuzinho: a arara azul está \\
hara = asa & vindo da direção do pôr do sol, gritando. \\
japànà = arara canindé & pyty = pôr do sol \\
rãã tê = azul e amarelo & rũmu = vindo \\
japy = rabo da arara & pànã rãre = arara azul \\
& càrà to pra haha = duas araras gritando \\
& hatoro = voar \\
\hline
\end{tabular}

Por fim, um canto do rito de fim de luto pàr-cahàc, que mostra claramente a ligação ao rito e a relação perspectiva entre vivos e espíritos de mortos. Como se sabe, os mortos são "outros" para os Krahô, "tidos como fundamentalmente diversos" (CARNEIRO DA CUNHA, 1978, p. 145). Os mortos (mekarõ) não se veem como mekarõ e veem os vivos como mekarõ e, assim, tem medo dos humanos (Idem, p. 70).

Jê pah pawre

Jê pah pawre

Johô hôre

Jê pah pawre

Jê pah pawre

Johô hôre

Johô hôre

Jê pah pawre

Jê pah pawre

Johô hôre

Hêêê hija mãnã jôhô hôre

hija mãnã jôhô hôre 
Tradução:

O espírito ouve ao longe a voz dos mehĩ cantando, com medo, "eu bem que lhe avisei que vocês não demoravam a morrer".

jê pah pawre $=$ medo do espírito

hija mãnã jôhô hôre = "eu bem que lhe avisei que vocês não demoravam a morrer"

Já na cantiga abaixo, o cantor canta sozinho, sem maracá, de madrugada, como numa convocação, para animar as pessoas a cantar no pátio. Não tenho, todavia, a informação sobre qual bicho canta essa música. A ocorrência do pronome com preposição ("para mim") que a inicia complexifica a construção, talvez no sentido do jogo de posição entre as entidades do canto:

Himã ropo hojê

Ropo hojê

Ropo hojê nẽ

Himã ropo hojê

Ropo hojê kaxê ti yo mõkra kama há hêêjõtoh nẽ

Tradução:

A luz da estrela bate na nuvem e a onça dorme na sombra daquela nuvem.

Himã = para $\operatorname{mim}$

ropo hojê = onça velha

kaxê ti = estrela grande

yo mõkra = sombra

kama = lá

há hêêjõtoh = está dormindo

\section{CONSIDERAÇÕES PARA FINALIZAR}

Os ritos krahô, assim como os seus cantos, são referidos a eventos ocorridos em tempos míticos. Essa é uma afirmação que fazem os Krahô: "aquele tempo, toda essa festa que estamos fazendo [fazíamos] é [era] imitando o que os bichos disseram para o 'pajé.' Pode ser batata, melancia, inhame, macaco, xexéu, peixe". Em alguns mitos, o personagem protagonista mesmo pode torna-se "pajé" para entender os cantos dos bichos. Há nisso uma alusão a relações próprias ao perspectivismo xamânico, que se congelou nos 
repertórios fixos de cantos krahô, mas ainda ecoa na sua estética: ora o jogo de perspectivas entre o bicho que canta e o bicho descrito, ora entre o bicho que canta o que é descrito e o cantador. Cantos em que os eventos e os seres não são resultado de uma operação imaginativa autoral, mas a descrição da cena que os bichos veem no momento xamânico (CESARINO, 2006).

No que tange à relação entre mitos e ritos, a repetição em um daquilo que está no outro é comum a outros povos ameríndios, mas entre os Krahô essa repetição não é a celebração do mito. Há, nos ritos, como que fragmentos desses mitos, personagens e elementos rituais evocados que estão nos mitos e podem ser identificados nos ritos. Melatti (1978) constatou a repetição transformacional entre ritos, e entre mitos e ritos, para a apreensão dos quais usou uma técnica que consiste em comparar certos detalhes entre ritos distintos, e comparar atos padronizados encenados por certos grupos rituais em ritos diferentes, os identificando relativamente. $\mathrm{O}$ autor constatou, também com essa técnica, diferenças entre grupos, personagens e elementos rituais que são identificados entre si. A profusão de ritos krahô torna essas identificações muito abundantes e difíceis de cercar. A inspeção da dinâmica transformacional entre ritos, mitos e cantos poderia apontar mais sobre os sentidos desses últimos, tarefa hercúlea também em vista da profusão de cantos.

Quanto aos conteúdos dos cantos, o recorte da imagem neles evocada, é mínimo, o que torna muito complexa a tarefa de associá-los em significado ao rito e ao jogo entre ritos e entre ritos e mitos. Mas, como dizem os Krahô, é dos amjĩ kĩn e dos cantos "que você vai tirar o seu sentimento da natureza". Ritos e cantos seriam então uma celebração de uma característica que atribuem a si mesmos, que é a de terem sido, quando se comparam aos não índios, originalmente "misturados com a natureza" e de terem aprendido tanto com a "natureza". Isso diz algo a respeito de cantores que cantam sempre as mesmas músicas e onde o mais importante é sua performatividade.

Chegamos, então, ao ponto em que, esta performatividade é questão quando se pensa a introdução dos cantos na escola? Os professores krahô afirmavam a necessidade, mas questionavam o caráter limitado do registro escrito e audiovisual de seus conhecimentos culturais, na medida em que se abre mão da performance desses conhecimentos e não se faz caso das intervenções necessárias no corpo para garantir-lhes a memória. Todavia, parecem convictos de que usar a escrita e a tecnologia audiovisual é o melhor recurso para guardarem esses seus "pertences". Poder-se-ia dizer, então, que o impulso 
"modernizador" dos professores krahô dirigia-se, entre outros aspectos, ao resguardo da "tradição" (tal como percebem que nós também o fazemos).

A imensa esperança e o sonho é ensinar na prática que meu povo continua mantendo para sempre e sugerimos arquivar nos computadores, livros, cds, até na sala de aula em contexto com as crianças em atividades para não esquecer a cantar as músicas. Ensinar através da escrita e oralmente como funciona o ritmo da música krahô, que pode ajudar os jovens de hoje e do futuro. E colocar no papel e divulgar para todas as escolas base, que os jovens de outras aldeias possam aprender a cantar. Isso ajuda o povo que não tem cantor [de aldeias krahô que não têm cantador] a cantar qualquer música.

A partir de todas as reflexões dos professores krahô em formação na UFG, acima apontadas, destaco, enfim, algumas ideias formuladas sobre a relação dos seus ritos e cantos com o que fundamentaria um projeto pedagógico próprio para suas escolas. Em primeiro lugar, a diferenciação que fazem entre "teoria" e "prática", remetendo a primeira ao conteúdo de livros e à fala de um professor em sala de aula - distante, portanto, da prática, ou de "praticar a cultura". Ou seja, os Krahô consideram que o seu processo de aprendizagem cultural, ou a aprendizagem de como ser um krahô e a aprendizagem daquilo que um krahô precisa saber, se faz" praticando" a cultura, sobretudo nos rituais, que incluem práticas corporais como pintura, corte de cabelo, corrida de toras, alimentação, resguardos, bem como cantar e dançar. Como dizem, na escola as crianças e os jovens aprenderiam por meio de ideias o que são tais práticas, mas não as vivenciariam. Esta é uma diferença pedagógica e uma questão fundamental que os professores krahô debatem, mas não só, posto que estão em fase de experimentação de formas pelas quais poderiam inclui-la em suas práticas pedagógicas em sua rica e profunda dimensão. Em segundo lugar, e como consequência, uma escola própria precisaria flexibilizar as fronteiras espaciais entre escola e pátio, o que já estão fazendo. Por fim, a contemplação de seus conhecimentos próprios na escola deverá, como também sinalizam, não simplesmente transpor os lugares que lhes cabem e internalizá-los - e artificializá-los ou minimizá-los nas salas de aula - mas potencializar lugares tradicionais de construção e transmissão e de experiência performatizada de tais conhecimentos e práticas. 
PERFORMANCE AND EDUCATION: A REFLECTION OF KRAHÔ TEACHERS ABOUT THE INCLUSION OF RITES AND SONGS IN PRACTICES OF INDIGENOUS EDUCATION

ABSTRACT: In order to contribute to the discussion of indigenous education, this article comments the Krahô teacher's reflection about incorporating their rituals and songs - axial actions in their culture - in their schools and in the very construction of their pedagogics projects. The text briefly presents stylistic and cosmological aspects of their performances and its connection with what we call "nature" and "supernatural". The analysis is based on observations and reflections joint with Krahô teachers in the context of their academic studies in intercultural education in the Federal University of Goiás.

KEYWORDS: Ritual. Songs. Krahô. Indigenous education.

\section{PERFORMANCE Y EDUCACIÓN: UNA REFLEXIÓN DE MAESTROS KRAHÔ SOBRE LA INCORPORACIÓN DE RITOS Y CANTOS EN LA PRÁTICA DE LA EDUCACIÓN ESCOLAR INDÍGENA}

RESUMEN: Con el fin de contribuir a la discusión de la educación escolar indígena, este artículo se ocupa de la reflexión de maestros Krahô acerca de la incorporación de su rituales y cantos - acciones axiales en su cultura - en sus escuelas y en la construcción autónoma de sus proyectos pedagógicos. Presenta brevemente los aspectos estilísticos y cosmológicos de su performance y su conexión con lo que llamamos "naturaleza" y "sobrenatural". El análisis es producto de observaciones y reflexiones conjuntas con profesores Krahô en el contexto de su formación en el curso de Educación Intercultural en la Universidad Federal de Goiás.

Palabras-clave: Ritual. Cantos. Krahô. Educación escolar indígena.

\section{NOTAS}

1) Adoto a grafia com inicial em minúscula da denominação de um povo com função de adjetivo (cantos krahô, professores krahô, por exemplo) e com inicial em maiúscula quando substantivo gentílico (os Krahô), como faculta a Convenção da grafia assinada na 1a Reunião Brasileira de Antropologia e como é usual nas publicações de etnologia indígena em português.

2) As palavras em língua krahô neste texto estão grafadas conforme indicação dos professores krahô, salvo quando se tratar de citações de outros autores - neste caso, mantenho a grafia apresentada pelos autores citados. Os Krahô estão em processo de fixação da grafia de sua língua. 
3) Acerca dessa descrição do comportamento dos seres nos cantos timbira, Azanha (2004), no encarte ao CD Amjëkin. Música dos povos timbira, pormenoriza: "... das pequenas bolhinhas d'água formadas pela rãnzinha amarela quando respira, à luz diáfana que emerge dos aerólitos; das cores inusitadas de determinadas joaninhas à forma delicada do menor dos arbustos e florzinhas do cerrado; da elegância do caminhar da onça à graça do redemoinho no cocuruto de um pequeno marsupial, tudo o que é diferencial e inusitado dos e nos seres é cantado"

\section{REFERÊNCIAS}

AZANHA, G. Encarte do CD Amjëkin. Música dos povos timbira. Centro de trabalho Indigenista/Petrobrás, 2004.

CARNEIRO DA CUNHA, M. Os mortos e os outros: uma análise do sistema funerário e da noção de pessoa entre os índios Krahó. São Paulo: Hucitec, 1978.

CESARINO, P. N. De duplos e estereoscópios: paralelismo e personificação nos cantos xamanísticos ameríndios. Mana, v. 12, n. 1, p. 105-134, abr. 2006.

COELHO DE SOUZA, M. Nós os vivos: "construção da pessoa" e "construção do parentesco" entre alguns grupos jê. Revista Brasileira de Ciências Sociais, v. 16, n. 46 p. 69-96, jun. 2001.

KRAHÔ, R. Y.; ALBUQUERQUE, F. E. Livro de alfabetização krahô. Fortaleza: Printcolor, 2009.

LADEIRA, M. E. A troca de nomes e a troca de cônjuges: uma contribuição ao estudo do parentesco timbira. 1982. 202 f. Dissertação (Mestrado em Antropologia). Departamento de Ciências Sociais, Faculdade de Filosofia, Letras e Ciências Humanas, Universidade de São Paulo, São Paulo, 1982.

. Timbira, nossas coisas e saberes. Coleções de Museus e produção da vida. São Paulo: CTI - Centro de Trabalho indigenista, 2012.

MELATTI, J. C. O mito e o xamã. Revista do Museu Paulista, v. 14, n.s., p. 60-70, 1963.

. Nominadores e Genitores: um aspecto do dualismo krahó. In: SCHADEN, E. (Org.) Leituras de Etnologia Brasileira. São Paulo: Companhia Editora Nacional, 1976. p. 139-148.

. Ritos de uma tribo Timbira. São Paulo: Ática, 1978.

. Nota sobre música Krahó. Revista Goiana de Artes, UFG, v. 3, n. 1, p. 29-40, 1982.

. Outras versões de mitos craôs. 2010. Disponível em: <http://www.juliomelatti.pro.br/craodados/craomitos.pdf>. Acesso em: 05 out. 2014.

NIMUENDAJU, C. The Eastern Timbira. Berkley/Los Angeles: University of California Press. (University of California Publications in American archeology and ethnology, vol. XLI), 1946. 
PECHINCHA, M. T. S. P. Teoria na cabeça versus teoria no papel: reflexões sobre conhecimento, oralidade e escrita na escola krahô. Tellus, ano 11, n. 20, p. 189-213, jan./jun. 2011.

(Org.). Crow kwỳ jarẽn xà. (Autores: Creuza Prum Kroi Krahô, Gregório Huhte Krahô, Dodanin Krahô, Renato Yahé Krahô, Roberto Cahxet Krahô, Isauro Krocok Krahô). Goiânia: FUNAPE/PROLIND, 2012.

RODRIGUES, A. D. Línguas brasileiras: para o conhecimento das línguas indígenas. São Paulo: Edições Loyola, 1986.

SEEGER, A. O que podemos aprender quando eles cantam? Gêneros vocais do Brasil Central. In: Os índios e nós. Rio de Janeiro: Campus, 1980. p. 83-104.

SETTI, K. Os sons do Përekahëk no rio Vermelho: um ensaio dos fatos musicais krahô. In: OVERATH, Johannes (Ed.). Musices Apatio. Die Musikkulturen der Indianer Brasiliens I. Roma: Consociatio Internationalis Músicae Sacrae, 1995. p. 183-239.

SIQUEIRA JR., J. Wyty-Catë: cultura e política de um movimento pan-Timbira: contribuição ao entendimento das organizações indígenas e novas expressões da política indígena. 2007. 350 f. Tese (Doutorado em Antropologia Social) - Departamento de Antropologia, Universidade de Brasília, 2007.

TUNGY, R. P. de. Apresentação. In: Cantos e histórias do morcego-espírito e do hemex. Rio de Janeiro: Beco do Azougue, 2009. p. 05-36.

VIVEIROS DE CASTRO, Eduardo. Os pronomes cosmológicos e o perspectivismo ameríndio. Mana, v. 2, n. 2, p. 115-144, out. 1996.

Mônica Thereza Soares PeCHincha: Doutora em Antropologia pela Universidade de Brasília $\left(U_{n B}\right)$. Atualmente é professora Adjunta da Universidade Federal de Goiás (UFG), nos cursos de Ciências Sociais e Licenciatura Intercultural de Formação de Professores Indígenas. Atua nas seguintes áreas: etnologia indígena, educação indígena e teoria antropológica.

E-mail: mpechincha@hotmail.com 